MICHAL GRZEGOREK

ORCID: 0000-0002-8763-4553

Politechnika Białostocka

WIESLAW TADEUSZ POPLAWSKI

ORCID: 0000-0003-0993-2173

Politechnika Białostocka

\title{
Konsumpcja usług w ramach miastotwórczej funkcji uzdrowisk
}

DOl: 10.19195/2083-7763.9.18

W dzisiejszych czasach można zaobserwować intensywną ingerencję człowieka w przestrzeń. Rozwój budownictwa, przemysłu, handlu, komunikacji i innych dziedzin działalności człowieka sprzyja powstawaniu nowych budowli stanowiących elementy zagospodarowania przestrzennego. Tendencje te wpisują się w nurt urbanizacji, zapełnienia przestrzeni geograficznej, ekonomicznej i społecznej tkanką miejską. Urbanizacja ma wiele wymiarów, gdyż jest to złożone zjawisko. Jednym $z$ determinantów rozwoju miast jest funkcja uzdrowiskowa.

Według Deana MacCannela ${ }^{1}$ współczesny człowiek to turysta. Czas wolny staje się podstawą tworzenia nowych społecznych struktur, wypiera stopniowo pracę z centrum układów społecznych. Zdrowie zajmuje niezmiennie wysoką pozycję w hierarchii wartości ludzkich. Starzenie się społeczeństw jest faktem, szczególnie w krajach wysoko rozwiniętych i państwach o wysokim wskaźniku urbanizacji. To wszystko składa się na rosnące zainteresowanie współczesnego człowieka rozmaitymi metodami powrotu do zdrowia, pełni sił witalnych, odnową biologiczną, fizyczną i psychiczną. Jedną z takich metod jest uczestnictwo w zorganizowanych lub indywidualnych wyjazdach do uzdrowisk w celu konsumpcji usług zdrowotnych. Zdzisław Szamborski (wybitny naukowiec zajmujący się turystyką zdro-

1 D. McCannel, The Tourist: A New Theory of the Leisure Class, London-Basingstoke 1976. 
wotną w latach 70-tych) wskazuje ${ }^{2}$, że ludzie uprawiają turystykę uzdrowiskową $\mathrm{z}$ chęci odnowienia własnych sił, w nieco mniejszym stopniu $\mathrm{z}$ chęci aktywnego wypoczynku i ze względu na stan zdrowia. Do realizacji tych celów dochodzi w uzdrowiskach, precyzyjnie określonych miejscach posiadających odpowiednie warunki klimatyczne i pobytowe. Przestrzeń turystyczna uzdrowiska staje się miejscem bytowania kuracjuszy, osób przyjeżdżających w celu konsumpcji usług w typie zabiegów odnowy biologicznej, często także zabiegów kosmetycznych oraz wypoczynku czynnego i biernego. Przestrzeń uzdrowiska wypełniona jest zatem specyficzną infrastrukturą, urządzeniami umożliwiającymi realizację celów turystów podejmujących ten rodzaj aktywności (konsumpcji). Rozbudowa i rozwój uzdrowiska polega więc nie tylko na ekspansji budownictwa mieszkaniowego, handlowego i usługowego, ale również na pojawianiu się w przestrzeni geograficznej, ekonomicznej i społecznej obiektów lecznictwa uzdrowiskowego, zakładów opieki medycznej, ośrodków zdrowia i urody itp. Można by rzec, że uzdrowisko rozwija się na podstawie dwu kategorii czynników: naturalnych i antropogenicznych. Do tych pierwszych zaliczyć można walory krajobrazowe, potencjał przyrodniczy, właściwości klimatyczne, występowanie naturalnych surowców (na przykład wód mineralnych); do drugich natomiast - wszelkie obiekty, działania, inicjatywy, budynki użyteczności publicznej, składniki infrastruktury - stworzone przez człowieka i służące szeroko pojętej urbanizacji. Część czynników antropogenicznych sprzyja rozwojowi turystyki uzdrowiskowej, stanowi mechanizm ją napędzający i usprawniający - dlatego czynniki te można uznać za zbiór determinantów rozwoju funkcji uzdrowiskowej. Siłą rzeczy usytuowane są one w kategorii wszystkich czynników antropogenicznych, ich rozwój może wynikać z rozwoju pozostałych (wszystkich) czynników bądź przybierać postać odrębnej ścieżki rozwojowej miasta. Innymi słowy, na rozszerzenie funkcji uzdrowiskowej w mieście mogą wpłynąć zarówno decyzje administracyjne dotyczące budowy nowych osiedli mieszkaniowych, obiektów rozrywkowych i kulturalnych - co wzmaga rozwój miasta poprzez napływ turystów zainteresowanych nowo otwartymi obiektami i przy okazji korzystających z walorów leczniczych miejscowości - jak i (a nawet przede wszystkim) pojawianie się w przestrzeni miasta miejsc przeznaczonych wyłącznie na potrzeby tego rodzaju turystyki - nowych sanatoriów, hoteli spa \& wellness, ośrodków wypoczynkowo-uzdrowiskowych, ścieżek zdrowia itp.

Należy pamiętać, że często funkcja uzdrowiskowa miasta współwystępuje z funkcją wypoczynkową i rekreacyjną. Inaczej mówiąc, rozwój funkcji uzdrowiskowej jest niejako pochodną rozwoju funkcji wypoczynkowej, istniejącej w specyficznych okolicznościach geograficznych, w miejscowości o statucie uzdrowiska. W pozostałych przypadkach, to znaczy w miastach nieposiadających (jeszcze)

2 Z. Szamborski, Turystyka zdrowotna uzdrowiskowa jako istotny element odnowy sił człowieka, "Zeszyty Naukowe IT” 1978, nr 6. 
statutu uzdrowiska, ekspansja funkcji wypoczynkowej nie sprawi, że przekształci się ona w funkcję uzdrowiskową. Na przykład w nadmorskich kurortach uzdrowiskowych, takich jak Kołobrzeg bądź Ustka, pojawia się coraz więcej obiektów hotelarskich świadczących usługi medyczne. Wcześniejsze ośrodki wypoczynkowe, nieodnajdujące się w warunkach gospodarki wolnorynkowej, zostały zamknięte bądź ogłosiły swoją upadłość, a na ich miejscu pojawiły się nowe, które do funkcji wypoczynkowej dołączyły usługi z zakresu lecznictwa uzdrowiskowego. W przypadku podobnych obiektów w miejscowościach nieposiadających statutu uzdrowiska (na przykład w Łebie czy we Władysławowie) nowe obiekty hotelarskie nie miały tak rozbudowanej bazy zabiegowej, a ich „funkcja uzdrowiskowa” ograniczała się w dużej mierze do salonów urody, urządzeń spa i wellness.

Wynika stąd, że funkcja miastotwórcza ma pierwotne usytuowanie czasoprzestrzenne, w miarę zaś rozwoju miasta pojawia się funkcja wypoczynkowa, a przy sprzyjających warunkach przyrodniczych, czego wyrazem jest posiadanie statusu uzdrowiska, miasto zostaje wzbogacone o funkcję uzdrowiskową. Powstaje jednak pytanie, czy taka chronologia pojawiania się funkcji jest jedyną możliwą na poszczególnych etapach rozwoju miasta? Istnieją miasta, których rozwój jest wynikiem innego układu wydarzeń. Genezą ich powstania było odkrycie właściwości leczniczych klimatu, pojawienie się bazy zabiegowej i obiektów przyrodoleczniczych, co pociągnęło za sobą rozwój miejscowości oraz rozbudowę funkcji turystycznej, w tym głównie wypoczynkowej.

Z powyższych wywodów wynika, że istnieją co najmniej dwie ścieżki rozwojowe miast uzdrowiskowych. Pierwsza polega na rozwoju miejscowości, nadaniu jej funkcji wypoczynkowej, a z czasem - po spełnieniu określonych warunków przyrodniczych - funkcji uzdrowiskowej. Taką ścieżkę rozwojową można byłoby roboczo nazwać funkcją wypoczynkowo-uzdrowiskową miasta. Druga ścieżka rozwojowa opiera się na pierwotnym istnieniu funkcji uzdrowiskowej, z której po upływie pewnego czasu wykształca się funkcja wypoczynkowa (w sprzyjających warunkach ekonomicznych i społecznych, a szerzej w odpowiednim układzie politycznym, demograficznym i geograficznym). Taki rozwój wydarzeń został roboczo określony mianem funkcji uzdrowiskowo-wypoczynkowej miasta, co pozwala uwypuklić funkcję uzdrowiskową, dzięki której istnieje miasto, przez umieszczenie jej w pierwszym członie nazwy. Pozostałe miejscowości, które nie posiadają potencjału leczniczego, spełniałyby w odniesieniu do wymienionych ścieżek funkcję wypoczynkową, gdyż realizują w mniejszym bądź większym stopniu rozwój walorów wypoczynkowych, charakterystyczny dla każdego miasta (pojawianie się parków, miejsc wypoczynku, lawek, ścieżek spacerowych). Istnienie trzech scenariuszy rozwojowych można wyrazić za pomocą schematów graficznych. W pierwszym scenariuszu (schemat 1) miasto przekształca się w kurort wypoczynkowy a następnie w uzdrowisko. Dominującą funkcją miastotwórczą jest w tym przypadku funkcja wypoczynkowo-uzdrowiskowa. 


\section{MIEJSCOWOŚĆ $\rightarrow$ FUNKCJA WYPOCZYNKOWA $\rightarrow$ FUNKCJA UZDROWISKOWA $\rightarrow$ MIASTO}

Schemat 1 .

Źródło: opracowanie własne.

Scenariusz drugi (schemat 2) zakłada istnienie walorów przyrodniczych i leczniczych, dających podstawę do formowania się osadnictwa i późniejszego nadania funkcji wypoczynkowej.

\section{MIEJSCOWOŚĆ $\rightarrow$ FUNKCJA UZDROWISKOWA $\rightarrow$ MIASTO $\rightarrow$ FUNKCJA WYPOCZYNKOWA}

\section{Schemat 2.}

Źródło: opracowanie własne.

W trzecim scenariuszu rozwojowym (schemat 3) w trakcie urbanizacji wieś lub małe miasto przeobraża się $\mathrm{w}$ większy organizm miejski, który, będąc pozbawionym potencjału przyrodoleczniczego, staje się miastem wzbogaconym o funkcję wypoczynkową.

\section{MIEJSCOWOŚĆ $\rightarrow$ MIASTO $\rightarrow$ FUNKCJA WYPOCZYNKOWA}

Schemat 3 .

\section{Źródło: opracowanie własne.}

Istnienie owych trzech scenariuszy rozwojowych można podeprzeć przykładami z Polski. Pierwszy scenariusz realizowany jest na przykład w Świnoujściu, które już w pierwszej połowie XIX wieku stało się kąpieliskiem morskim (oficjalnie w 1827 roku, choć pierwsze działania służące założeniu kąpieliska podjęto w roku 1824), a dopiero w 1897 roku odkryto na terenie miejscowości zasoby leczniczej solanki, która dała przyczynek do rozbudowy funkcji uzdrowiskowej. Walory uzdrowiskowe Świnoujścia to między innymi dostęp do dziesięciokilometrowego odcinka plaży nadmorskiej osiągającej szerokość ponad 70 metrów, łagodny i zdrowy klimat, zasoby borowin ze złóż typu niskiego i wysoko zmineralizowanych wód chlorkowo-sodowych, solanek bromkowo-żelazisto-borowych ${ }^{3}$. Miejscowość jest silnie zurbanizowana, gęsto zaludniona, ale jednocześnie jej powierzchnię w dużym stopniu pokrywają parki i tereny zielone. Mimo że Świnoujście uzyskało prawa miejskie w 1765 roku, swój rozwój zawdzięcza, prócz funkcji portowej, głównie turystyce, a także istnieniu uzdrowiska.

Drugą ścieżkę rozwojową reprezentuje w Polsce na przykład Ciechocinek. Pierwsze odwierty w celu pozyskania soli wykonano tam w 1791 roku, w 1824 roku

${ }^{3}$ M. i R Łazarkowie., Uzdrowiska w Europie. Teraźniejszość i rys historyczny, Lublin 2007. W. Maik, Podstawy geografi miast,Toruń 1992. 
rozpoczęto budowę tężni solankowych, a w 1836 roku ustawiono pierwsze wanny kąpielowe do wykonywania zabiegów leczniczych ${ }^{4}$. Specyfika właściwości leczniczych miejscowości polega na występowaniu soli zawierających chlorek wapnia, magnezu, dwuwęglanu żelaza i siarczanu wapnia, co sprzyja uzupełnianiu niedoborów mikroelementów w organizmie ludzkim ${ }^{5}$. Uzdrowisko otrzymało prawa miejskie dopiero w 1916 roku, co dowodzi faktu, iż funkcja uzdrowiskowa poprzedzała procesy urbanizacyjne i przyczyniła się do rozwoju miasta. W ostatnich latach w Ciechocinku pojawiają się obiekty hotelarskie o wysokim standardzie, które nastawione są na turystów realizujących w uzdrowisku pobyty wypoczynkowe.

Trzecią ścieżkę rozwoju miast (z pominięciem funkcji uzdrowiskowej) reprezentuje na przykład Zakopane. Miejscowość nie posiada statutu uzdrowiska, a jej rozwój opiera się wyłącznie na rozbudowie rozmaitych możliwości spędzania czasu wolnego w formie wypoczynku czynnego i biernego. Nowe obiekty hotelarskie odnoszą się w pewnym zakresie do funkcji odnowy biologicznej, upiększania i relaksu, lecz baza zabiegowa nie jest rozbudowywana w kierunku lecznictwa, jak $\mathrm{w}$ tradycyjnych uzdrowiskach.

Dla lepszego rozumienia ścieżek rozwojowych uzdrowisk i ich miastotwórczej funkcji niezbędne jest zdefiniowanie uzdrowiska. Za uzdrowisko uważa się miejscowość (wieś lub miasto), która obfituje w naturalne czynniki lecznicze (na przykład borowiny, klimat, wody mineralne $)^{6}$. W uzdrowisku wykorzystuje się różnego rodzaju formy energii w celu poprawienia stanu zdrowia (pole magnetyczne, ultradźwięki, światło itp.). Właściwości lecznicze posiadają również zasoby naturalne, na przykład gazy (dwutlenek węgla, siarkowodór), woda (hydroterapia i balneoterapia $\mathrm{z}$ szerokim zastosowaniem wody $\mathrm{w}$ inhalacjach, natryskach, kąpielach, okładach, masażach itp.), a także właściwości klimatyczne. Ustawa z dnia 28 lipca 2005 roku wyszczególnia warunki, jakie muszą zostać spełnione przez daną miejscowość przed nadaniem jej statutu uzdrowiska ${ }^{7}$. Do najważniejszych należą: posiadanie złóż surowców leczniczych naturalnego pochodzenia, obecność klimatu wpływającego leczniczo na organizm ludzki, istnienie zakładów i urządzeń służących lecznictwu uzdrowiskowemu oraz spełnianie ściśle określonych rygorów $\mathrm{w}$ stosunku do środowiska przyrodniczego. Akt nadania statutu uzdrowiska dokonywany jest przez Radę Ministrów w formie rozporządzenia i na wniosek ministra właściwego dla kwestii związanych ze zdrowiem i opieką medyczną. Ustawa określa również rodzaje uzdrowisk pod względem kryterium położenia geograficznego, wyróżniając uzdrowiska nadmorskie, nizinne, podgórskie i górskie. W Polsce status uzdrowiska posiada 45 miejscowości.

${ }^{4}$ Ibidem, s. 67.

5 Ibidem, s. 68.

6 J. Kraś, Istota i znaczenie turystyki uzdrowiskowej w Polsce, „Seminare” 29, 2011.

7 Ustawa z dnia 28 lipca 2005 r. o lecznictwie uzdrowiskowym, uzdrowiskach i obszarach ochrony uzdrowiskowej oraz gminach uzdrowiskowych, Dz.U. Nr 167, poz. 1399 z późn. zm. 
Miastotwórczą funkcję uzdrowisk tworzą pojawiające się $\mathrm{w}$ przestrzeni nowe obiekty, budynki użyteczności publicznej. O uzdrowiskowym charakterze miasta może świadczyć obecność między innymi szpitali uzdrowiskowych, sanatoriów, prewentoriów, przychodni uzdrowiskowych, pijalni wód mineralnych, parków zdrojowych, ścieżek zdrowia, basenów termalnych i promenad spacerowych. Obiekty tego typu charakteryzują się stosunkowo ścisłym porządkiem usytuowania w przestrzeni uzdrowiska, co wynika $\mathrm{z}$ istnienia tak zwanych trzech stref ochronnych uzdrowiska („A”, „B”, „C”). W strefie A przeważają zakłady lecznictwa uzdrowiskowego i obiekty turystyczne tworzące szeroko rozumianą bazę hotelarską i gastronomiczną. Strefę B, usytuowaną w otulinie strefy A, stanowią obszary usługowe, turystyczne i rekreacyjno-sportowe. Strefa B jest zaś otoczona strefą C, której celem istnienia jest ochrona walorów klimatyczno- krajobrazowych oraz złóż surowców używanych w lecznictwie ${ }^{8}$.

Funkcjonowanie walorów uzdrowiskowych jako czynnika miastotwórczego jest szczególnie wyraźne w przypadku miejscowości o długoletnich tradycjach leczniczych. Rozwój tych miejscowości, rozbudowa tkanki miejskiej, przydanie nowych funkcji następowało na podstawie swoistej bazy miastotwórczej, której rdzeniem było istnienie „wód i zdrojów”. W XIII wieku odkryto pierwsze termy lecznicze w Cieplicach Śląskich, przy czym w XVII wieku znane były one już w całej Europie. Początki lecznictwa uzdrowiskowego w Lądku-Zdroju również sięgają XIII wieku. W krakowskiej dzielnicy Swoszowice zainaugurowano działalność prozdrowotną w XVIII wieku, a około 100 lat później odnotowano rozkwit Krynicy-Zdroju. Niemałą rolę w rozbudowie uzdrowiska krynickiego odegrała linia kolejowa łącząca miejscowość z Muszyną. Na XIX wiek przypadł również rozwój Szczawnicy, Dusznik-Zdroju, Buska-Zdroju, Ciechocinka, Nałęczowa, Otwocka i Solca-Zdroju. Czasem wzmożonego rozwoju uzdrowisk i ich rozbudowy przestrzennej były w szczególności lata 60. i 70. XX wieku. Stawiano wówczas całe dzielnice sanatoryjne zakładów pracy lub innych instytucji państwowych. Największy rozkwit przestrzeni miejskiej przeżywały wtedy Kołobrzeg, Ustronie, Krynica, Ciechocinek, Busko-Zdrój, Iwonicz i Szczawnica.

Przemiany polityczno-ekonomiczne lat 90 . XX wieku zapoczątkowały trudny okres w funkcjonowaniu uzdrowisk. Drastyczne ograniczenia nakładów finansowych z budżetu państwa na rozbudowę uzdrowisk doprowadziły do przekształceń własnościowych, restrukturyzacji oraz likwidacji niektórych obiektów. Nowa sytuacja wymusiła zmiany i w ciągu zaledwie dziesięciolecia dostosowano się do wolnego rynku w segmencie usług medycznych i uzdrowiskowych. W życie wcielono inne formy organizacji i zarządzania, opierające się na konkurencyjności i marketingu. W XXI wieku pojawiły się nowe miejscowości o statucie uzdrowiska (Gołdap, Supraśl, Krasnobród i Dąbki). Zmiany historyczne, polityczne,

8 J. Kraś, op. cit. 
ekonomiczne i społeczne odbiły się na przestrzennym układzie uzdrowisk, w ich funkcji miastotwórczej.

Nie bez znaczenia dla rozwoju miasta jest funkcja komunikacyjna. Sieć komunikacyjna odgrywa niezwykle istotną rolę w kształtowaniu gospodarki i powiązań ekonomicznych. Transport jest niejako układem krążenia gospodarki. Relację między transportem a turystyką ( $w$ tym uzdrowiskową) można porównać do sprzężenia zwrotnego. Turystyka rozwija się dzięki istnieniu transportu, który dostarcza turystów do miejsc recepcyjnych, w których dochodzi dokonsumpcji usług turystycznych; z drugiej strony transport rozwija się dzięki ruchliwości przestrzennej ludzi, w której niemałą rolę (szczególnie w miejscowościach turystycznych) odgrywa turystyka. Sprzężenie to istnieje od początku funkcjonowania turystyki i jest $\mathrm{z}$ nią zespolone. Powiązania transportu $\mathrm{z}$ innymi przejawami gospodarki (w tym z turystyką) mogą wpływać na urbanizację. Niegdyś podróż z Krakowa do Krynicy pokonywano konno, następnie dorożką. Dopiero rozwój komunikacji oraz środków masowej komunikacji i reklamy przyczyniły się do wzrostu popularności tego uzdrowiska, w szczególności wśród mieszkańców Krakowa, z czasem wśród mieszkańców całej Polski, Europy, świata. Krynica przyciągała architektów, przedsiębiorców, letników, nowych mieszkańców. Nastąpił przestrzenny rozwój miejscowości, zajmującej z czasem kolejne doliny. Z początku, gdy motoryzacja nie była jeszcze rozpowszechniona (w szczególności w XIX wieku), na miastotwórczą funkcję miały wpływ koleje. Pojawienie się regularnych połączeń komunikacyjnych (autobusowych, kolejowych, przewozów realizowanych mikrobusami) przełożyło się, nie tylko w Krynicy, na zwiększenie mobilności, na łatwiejszą dostępność pasażerów i towarów, ożywienie gospodarcze regionów. Bardzo często podczas lektury i analizy map gospodarczych można dostrzec pokrywanie się obszarów dużej koncentracji ludności z terenami o rozbudowanej sieci komunikacyjnej.

Miastotwórczą rolę uzdrowiska pod względem dostępności komunikacyjnej dobrze ilustruje przykład Nałęczowa, w którym jeszcze w XX wieku zabudowa uzdrowiskowa była wyraźnie skupiona w centralnej części miejscowości, w parku zdrojowym i na jego obrzeżach. $Z$ czasem uzdrowisko zaczęło rozwijać się w kierunku północnym, to jest na terenie położonym pomiędzy centralnie usytuowanym dworcem autobusowym a stacją kolejową. W wymienionym obszarze pojawiły się w XXI wieku nowe obiekty hotelarskie świadczące usługi wellness, spa \& beauty, takie jak: Willa Orle Gniazdo, Dwór Nałęczowski Vitaligs SPA, Wellness \& SPA W Krainie Alicji. Rozbudowa funkcji uzdrowiskowej (funkcji wellness i spa) pociągnęła w kierunku północnym (w stronę stacji kolejowej) rozrost funkcji mieszkaniowej (między innymi powstanie apartamentowców przy ulicy Kolejowej), a w dalszej kolejności funkcji handlowej i usługowej. Podobną tendencję zauważyć można w Nałęczowie w dzielnicach wschodnich. Nowe obiekty spa \& wellness wybudowano wzdłuż alei Lipowej (Willa Raj, Willa Aurelia). Pojawienie się obiektów spa spowodowało zatem zurbanizowanie tego terenu. To niewątpliwy dowód na istnienie zależności pomiędzy uzdrowiskami 
a urbanizacją, na funkcjonowanie miastotwórczej roli uzdrowisk. Należy zauważyć, że pozostałe kierunki (południowy i zachodni) nie miały aż takich szans na rozwój miasta z uwagi na istnienie pewnych przeszkód. W przypadku kierunku zachodniego barierą jest park zdrojowy, rozciągający się w stronę zachodnią prawie do granic zabudowy miasta; południową przeszkodę stanowi natomiast bariera naturalna w postaci głębokiego wąwozu doliny rzeki Bystrej.

Rozważania na temat przestrzeni miejskiej uzdrowisk wiążą się z geografią miast. Miejscowości uzdrowiskowe często stanowią ośrodki miejskie (na przykład Świnoujście, Augustów), niekiedy zaś dzielnice miast (na przykład SwoszowiceKraków, Cieplice Śląskie-Zdrój jako dzielnica Jeleniej Góry). Niekiedy uzdrowiska stają się częścią aglomeracji policentrycznej (na przykład Sopot stanowiący integralną część tak zwanego Trójmiasta) oraz monocentrycznej (na przykład Konstancin-Jeziorna jako fragment obszaru metropolitarnego miasta stołecznego Warszawy). W sensie przestrzennym miasto jest obszarem największej koncentracji zarówno ludności, jak i zabudowy. Takie swoiste nagromadzenie problemów natury ekonomicznej, politycznej, kulturowej, administracyjnej sprawia, że miasto jest trudnym, ale i wyjątkowo interesującym obiektem badań naukowych zarówno dla socjologów, jak i geografów. Wiesław Maik ${ }^{9}$ wyróżnia główne problemy badawcze geografii miast, do których zalicza: zagadnienia powstania i rozwoju miast (urbanizacja), wewnętrznego zróżnicowania miast - według pełnionych funkcji oraz relacji międzymiejskich, a także między miastem a wsią. Nowym zjawiskiem, któremu poświęcono liczne opracowania, jest kontrurbanizacja, czyli spadek udziału wielkich miast w ogólnej liczbie ludności miejskiej na skutek przemian demograficznych (starzenia się społeczeństw) oraz deindustrializacji i wzrostu znaczenia walorów środowiska naturalnego. Zagadnieniem tym zajmował się Jerzy Grzeszczak ${ }^{10}$. Jak zauważa Witold Kusiński ${ }^{11}$, rozwój geografii miast wymaga tworzenia ścisłych powiązań przede wszystkim z socjologią i ekonomią. Należy pamiętać, że funkcja uzdrowiskowa nie jest w większości przypadków wiodąca. Większość miast jest polifunkcyjnych, przez co funkcję dominującą należy traktować jako pewien rodzaj specjalizacji miasta ${ }^{12}$. Funkcja uzdrowiskowa rozumiana jako podfunkcja turystyki wpisuje się w typ funkcji o charakterze usługowym. Jak zauważa Waldemar Budner, o dynamice rozwojowej miast zaczynają w coraz większym zakresie decydować funkcje usługowe,

9 W. Maik, Podstawy geografii miast, Toruń 1992.

10 J. Grzeszczak, Tendencje kontrurbanizacyjne w krajach Europy Zachodniej, „Prace Geograficzne 167", Wrocław 1996.

11 W. Kusiński, W sprawie nowych kierunków geograficznych badań obszarów miejskich, Wrocław 1996.

12 M. Jerczyński, Funkcje i typy funkcjonalne polskich miast, [w:] Statystyczna charakterystyka miast. Funkcje dominujące, red. K. Dziewoński, M. Jerczyński, Warszawa 1977. 
pojawiające się ze szczególnym nasileniem $\mathrm{w}$ warunkach gospodarki wolnorynkowej ${ }^{13}$. Miasta jako wyższe formy rozwojowe osiedli ludzkich są w głównej mierze pojęciem przestrzennym. Kazimierz Trafas określa je jako emanację bytu spolecznego $\mathrm{w}$ przestrzeni ${ }^{14}$. Przestrzeń miejska to typ przestrzeni geograficznej wyróżniający się specyficzną organizacją i fizjonomią oraz określonym statusem prawnym ${ }^{15}$.

Innym aspektem odnoszącym się do miastotwórczej roli uzdrowisk jest estetyka przestrzeni. Rozwój miasta wpływa na rozwój turystki, ten zaś może przyczynić się do poprawy estetyki miasta, czego wyrazem jest rewitalizacja pewnych kwartałów przestrzeni miejskiej. Przykładem odnoszącym się do polskich uzdrowisk jest sposób przeprowadzenia tego rodzaju odnowy w Kołobrzegu. Jak podaje Wydział Rozwoju Miasta ${ }^{16}$, w latach 2010-2013 zrewitalizowano Kołobrzeską Strefę Uzdrowiskową. W szczególności odnowiono park miejski i park nadmorski, wybudowano szlaki turystyczne i zmodernizowano tereny rekreacyjno-sportowe. Innymi przejawami rewitalizacji są na przykład: przebudowa parku zdrojowego w Polanicy-Zdroju ${ }^{17}$ w ramach Regionalnego Programu Operacyjnego na lata 2007-2013 czy kompleksowa rewitalizacja parku zdrojowego w Rabce-Zdroju ${ }^{18}$, którą podjęto w latach 2010-2012.

Funkcja uzdrowiskowa jest niewątpliwie jednym z istotniejszych czynników wpływających na formowanie się przestrzeni miejskiej (na urbanizację). Wpływ tej funkcji na urbanizację jest szczególnie widoczny w małych miejscowościach, w których funkcja uzdrowiskowa jest wyraźniejsza i stanowi swego rodzaju dominantę. Obiekty sanatoryjne i całe uzdrowiskowe dzielnice stanowią bowiem niekiedy znaczny fragment powierzchni miasta, ich oddziaływanie na gospodarkę i społeczeństwo jest na tyle wyraźne, że przeobrazić się mogą w profil funkcjonowania miasta. Rozbudowa infrastruktury uzdrowiskowej, obiektów lecznictwa i bazy towarzyszącej sprzyja formowaniu się miast (urbanizacji). Istotnym elementem jest promocja uzdrowiska, zarówno wśród kuracjuszy, jak i szerzej, wśród turystów, którzy mogą wykorzystywać jego funkcje uzdrowiskowe do organizacji wypoczynku, zwłaszcza rodzinnego, na przykład w czasie pobytu w górach

13 W. Budner, Funkcje administracyjne a struktura funkcjonalna miast średnich $i$ dużych, „Przegląd Geograficzny” 71, 1999, nr 4.

${ }^{14}$ K. Trafas, Miasto jako obiekt badań geoinformatycznych, „Geoinformatica Polonica” 2003, nr 5.

15 S. Liszewski, Rola i zadania geografii w badaniach zróżnicowania przestrzennego warunków życia mieszkańców miast. Założenia teoretyczne i program badań, [w:] Zróżnicowanie warunków życia ludności w mieście, red. I. Jażdżewska, Łódź 2004.

16 Oficjalna strona Wydziału Rozwoju Miasta Kołobrzeg: http://www.wrm.kolobrzeg.eu/rewitalizacja_strefy_uzdrowiskowej.htm (dostęp: 22.11.2018).

17 Oficjalna strona miasta Polanica-Zdrój: http://polanica.pl/strona-236-przebudowa_parku_ zdrojowego_w_polanicy.html (dostęp: 22.11.2018).

18 Oficjalna strona miasta Rabka-Zdrój: http://www.rabka.pl/index.php?komunikat=271 (dostęp: 22.11.2018). 
czy nad morzem. Promocja może dotyczyć infrastruktury, funkcji leczniczej, wypoczynkowej, a także palety usług. Dzięki promocji możemy dotrzeć do nowych segmentów, na przykład pojawiająca się ostatnio moda na pobyty uzdrowiskowe wśród klientów z zamożnych państw arabskich. Strategia promocji regionalnej, a nawet inwestycyjnej, może wychodzić temu naprzeciw, na przykład przez misje gospodarcze $\mathrm{w}$ krajach arabskich mające na celu przyciągnięcie nowych inwestycji hotelarsko-uzdrowiskowych, czy nawet stworzenie obiektów dostosowanych do ich potrzeb (chodzi o specyfikę jedzenia halal czy oddzielnych, specjalnie zaprojektowanych obiektów dla kobiet). Potrzebne są kampanie promocyjne skierowane do kuracjuszy i turystów z krajów wschodnich, jak również do Czechów, Słowaków, Węgrów czy Rumunów, a nawet Austriaków. Pobyt w polskich uzdrowiskach jest poza tym znacznie tańszy, podobnie jak korzystanie z innych elementów infrastruktury turystycznej. Wielkie wydarzenia, jak na przykład festiwale imienia Jana Kiepury w Krynicy czy szopenowski w DusznikachZdroju są poza Polską słabo rozpropagowane, a mogą być dobrym instrumentem promocji.

Przykład wielu miejscowości uzdrowiskowych dowodzi, że odkrycie złóż surowców naturalnych lub wykazanie leczniczych właściwości klimatu w znacznym stopniu ożywia daną miejscowość pod względem gospodarczym, społecznym i przestrzennym, co z kolei tworzy podstawy do nadania praw miejskich i przyczynia się do postępu urbanizacji. Uzdrowisko w miarę swojego rozwoju ma szansę stać się miastem. Przy zachowaniu względnie nienaruszonych zasobów przyrodniczych, przy właściwie funkcjonującej organizacji i marketingu, przy sprostaniu oczekiwaniom kuracjuszy pod względem komunikacji, wreszcie przy świadczeniu usług o pożądanym standardzie - uzdrowisko ma szansę na rozwój i konkurencyjność na rynku usług leczniczych. Siłą witalną miasta może stać się jego oblicze uzdrowiskowe, siłą napędową uzdrowiska — miasto.

\section{Bibliografia}

Budner W., Funkcje administracyjne a struktura funkcjonalna miast średnich i dużych, „Przegląd Geograficzny" 71, 1999, nr 4.

Grzeszczak J., Tendencje kontrurbanizacyjne w krajach Europy Zachodniej, „Prace Geograficzne 167", Wrocław 1996.

http://polanica.pl/strona-236-przebudowa_parku_zdrojowego_w_polanicy.html(dostęp:22.11.2018). http://www.rabka.pl/index.php?komunikat=271 (dostęp: 22.11.2018).

http://www.wrm.kolobrzeg.eu/rewitalizacja_strefy_uzdrowiskowej.htm (dostęp: 22.11.2018).

Jerczyński M., Funkcje i typy funkcjonalne polskich miast, [w:] Statystyczna charakterystyka miast.

Funkcje dominujące, red. K. Dziewoński, M. Jerczyński, Warszawa 1977.

Kraś J., Istota i znaczenie turystyki uzdrowiskowej w Polsce, „Seminare” 29, 2011.

Kusiński W., W sprawie nowych kierunków geograficznych badań obszarów miejskich, Wrocław 1996. 
Liszewski S., Rola i zadania geografii w badaniach zróżnicowania przestrzennego warunków życia mieszkańców miast. Założenia teoretyczne i program badań, [w:] Zróżnicowanie warunków życia ludności w mieście, red. I. Jażdżewska, Łódź 2004.

Łazarkowie M. i R., Uzdrowiska w Europie. Teraźniejszość i rys historyczny, Lublin 2007.

Maik W., Podstawy geografii miast, Toruń 1992.

McCannel D., The Tourist: A New Theory of the Leisure Class, London-Basingstoke 1976.

Szamborski Z., Turystyka zdrowotna uzdrowiskowa jako istotny element odnowy sił człowieka, „Zeszyty Naukowe IT" 1978, nr 6.

Trafas K., Miasto jako obiekt badań geoinformatycznych, „Geoinformatica Polonica” 2003, nr 5.

Ustawa z dnia 28 lipca 2005 r. o lecznictwie uzdrowiskowym, uzdrowiskach i obszarach ochrony uzdrowiskowej oraz gminach uzdrowiskowych, Dz.U. Nr 167, poz. 1399 z późn. zm.

\section{The consumption of services as part of the city-forming function of health resorts}

\section{Summary}

The development of health tourism contributes to urbanization. The existence of a city can be the driving force of a spa. There are various developmental scenarios of spas in the light of their city-forming function. The spa function of the city can be read on the basis of the analysis of the space and objects constituting it. Sanatoriums, physiotherapy objects or facilities that provide therapeutic treatments and their development influence urbanization. An important factor of the development of cities (including health resorts) is communication. The esthetics of urban space is a factor conducive to urbanization in the spa areas. Cultural events can be an important instrument for the promotion of spa towns. 